Hydrology and Earth System Sciences, 2(1), 65-76 (1998) C EGS

\title{
Use of deuterium to understand runoff generation in a headwater catchment containing a dambo
}

\author{
M.P. McCartney, C. Neal and M. Neal \\ Address of all authors: Institute of Hydrology, Maclean Building, Crowmarsh Gifford, Wallingford, Oxfordshire OX10 8BB.
}

\begin{abstract}
Dambos, seasonally saturated wetlands, are widespread in headwater catchments in southern Africa and play an important role in the regional hydrological cycle. However, the processes influencing runoff from these catchments are poorly understood. This paper reports an isotopic investigation of runoff-generating mechanisms within a Zimbabwean catchment containing a dambo. Hydrograph separation using deuterium reveals that, once the dambo is saturated, up to $70 \%$ of total storm flow can be considered 'new' water (i.e. derived directly from rainfall generating the runoff event). However, both the total proportion and the instantaneous maximum amount of 'new' water in hydrographs are sensitive to rainfall characteristics and antecedent conditions. These results are (1) compatible with observations made in catchments in temperate climates when wetlands are present, and contrast with results obtained when wetlands are absent and (2) consistent with saturation overland flow, generated in saturated regions of the dambo, being the major storm runoff mechanism. To reconcile these observations with past perceptions that dambos attenuate flood flows, a dual role for dambos in storm flow production is postulated.
\end{abstract}

\section{Introduction}

The hydrological response of a catchment to rainfall depends on the interplay between climatic, geological and land-use variables. Stormflow in headwater streams results from water entering the channel via either subsurface or overland flow paths (Ward, 1984). Overland flow is generated as a consequence of rainfall intensity exceeding the infiltration capacity of the soil prior to the soil being saturated (so called Hortonian overland flow), or because the watertable rises to the ground surface, thereby reducing the infiltration capacity to zero, so that all precipitation, falling at whatever intensity, generates saturation overland flow. The dominance of overland flow in a storm hydrograph depends on the permeability of the soil, rainfall intensity and duration, and catchment relief and geometry (Dubreuil, 1985; 1986).

Wetland features, known as dambos, are common in many headwater catchments in southern Africa. In Zimbabwe, it is estimated that they occupy 1.3 million ha, close to $4 \%$ of the country's area (Whitlow, 1984). Described as 'seasonally materlogged, predominantly grasscovered, shallow, linear depressions in the headward zones of rivers' (Mackel, 1974), dambos show considerable variation in physical attributes. Common features are their low relief and poorly-drained soils. Dambos can be considered as 'receiving sites' or interruptions to water moving from the upland slopes (the interfluve) to the stream channel. Thus, their form, function and maintenance are governed by the soil and hydrological processes on the upland slopes, as well as by processes within the dambo itself.

At present, there is no consensus amongst researchers on the influence exerted by dambos on flood flows. There has long been a widely-held perception that dambos attenuate flood hydrographs by providing storage and by their vegetation impeding runoff (e.g. Kanthack, 1945; Drayton et al., 1980). Other empirical studies have produced seemingly conflicting results. In a study of four small catchments in northern Zambia, catchments with greater areas of dambo were found to generate greater surface runoff and higher peak flows (Balek and Perry, 1973). However, it was also observed that overland flow from dambos was prolonged 'as compared with a non-swampy area of similar shape and size' because of 'the resistance of dambo grasses toward the flow.' Using a regional approach, Bullock (1992) demonstrated that, within Zimbabwe, there is no evidence to suggest that dambos exert any significant influence on flood magnitude-frequency relationships but postulated that 'catchments containing higher proportions of dambos exhibit greater potential for extreme floods than catchments with lower dambo density.' A limitation of the regional approach, however, is that it treats dambos as 'black boxes' and does not provide any information on the mechanisms of runoff generation. 
Over the last three decades, the practice of using hydrochemistry as a diagnostic tool to increase understanding of catchment hydrology and to identify flow paths, has been used in many different environments. The use of naturallyoccurring isotopes (e.g. deuterium and oxygen-18) to separate streamflow into different runoff components is well established (e.g. Pearce et al., 1986; Bonell et al., 1990; Wels et al., 1991). However, few chemical studies of streamflow generation have been conducted in the tropics, particularly in Africa. An exception is the study of Sandström (1996) which reports on the hydrochemical separation (based on end-member chemistry) of storm hydrographs in a small $\left(2.8 \mathrm{~km}^{2}\right)$, moderately steep (slopes up to $20^{\circ}$ ), forested catchment in a semi-arid region of Tanzania with a bimodal rainfall regime. In this catchment, the perennial stream originates in a 'mbuga' (the local name for a dambo) but of unstated size. Results indicated that 'new' water comprised up to $75 \%$ of total stormflow. Although saturation overland flow was noted on the dambo, a significant proportion of the runoff generation within the catchment was attributed to Hortonian overland flow.

Against this background, this paper reports on what is possibly the first environmental isotope study to provide an insight into the runoff-generating processes occurring within a catchment containing a dambo. Knowledge of storm-runoff processes within dambos is important because their valley bottom location and their common occurrence in headwater catchments ensure that they have far-reaching effects on the hydrological regime of river basins.

\section{The use of deuterium in storm hydrograph separation}

Oxygen and hydrogen isotopes in water are not chemically fractionated, so the isotopic content of water will change only as a consequence of physical processes such as mixing of water types and partial evaporation. Isotopic fractionation occurs on partial evaporation of water because isotopically light water molecules (i.e. ${ }^{1} \mathrm{H}_{2}{ }^{16} \mathrm{O}$ ) evaporate more efficiently than the heavy ones (i.e. ${ }^{1} \mathrm{HD}^{16} \mathrm{O}$ and ${ }^{1} \mathrm{H}_{2}{ }^{18} \mathrm{O}$ : where $\mathrm{D}$ is deuterium $\left({ }^{2} \mathrm{H}\right)$, the heavy isotope of hydrogen).

The isotopic content of stream water represents the volumetric integration of the isotopic contents of the different water sources existing in a catchment and rainfall that contribute to it. Deuterium exhibits conservative behaviour on mixing and so can be used to estimate the direct input of precipitation into streamflow during an event and to split the event hydrograph into 'new' and 'old' water. 'New' water is defined as the rainwater that generates a specific flow event, which is present in the stream as part of the hydrograph response from that event. 'Old' water is defined as water from preceding rainfall events and present in the catchment prior to the current event. Isotopic hydrograph separation does not distinguish flowpaths. 'New' water may enter the stream through surface runoff or rapid throughflow. 'Old' water may be contributed from several sources: groundwater (saturated zone water), unsaturated zone soil water and standing surface water.

At any given time, the fraction of the total stream discharge which is contributed by 'new' and 'old' water can be computed by solving the following simultaneous equations:

$$
\begin{aligned}
Q_{t} & =-Q_{n}+Q_{o} \\
C_{t} Q_{t} & =C_{o} Q_{o}+C_{n} Q_{n}
\end{aligned}
$$

where:

$Q_{t}=$ total (measured) discharge

$Q_{n}=$ contribution of new water to streamflow

$Q_{o}=$ contribution of old water to streamflow

$C_{t}=$ deuterium measured in the stream water at any time during the event

$C_{n}=$ deuterium measured in 'new' water (i.e. the rainfall signal)

$C_{o}=$ deuterium measured in 'old' water (i.e. the signal in the stream before the start of the event)

Deuterium concentrations are generally expressed as $\delta D$ values which are per mil (i.e. parts per thousand) variations with respect to an internationally agreed composition of ocean water, Vienna Standard Mean Ocean Water (VSMOW):

$$
\delta D(\% o)=\frac{\left(D / /^{1} H\right)_{\text {sample }}-\left(D /{ }^{1} H\right)_{S M O W}}{\left(D / /^{1} H\right)_{S M O W}} \times 1000
$$

Waters with less and more deuterium than V-SMOW have negative and positive $\delta D$ respectively.

The deuterium signal of rainfall varies between storm events, and is dependent on the temperature at which oceanic water is evaporated into the air, the temperature of condensation at which clouds and the rain are formed, and the amount of rainfall making up an event (Clark and Fritz, 1997). The deuterium signature of soil water and groundwater is a damped reflection of the medium to longterm precipitation inputs. It is the contrast between the more variable signature of precipitation inputs (new water) and the more uniform signature of soil water and groundwater (old water) that provides the basis for hydrograph separation. In this study, deuterium has been used to investigate volumetric contributions of 'new' and 'old' water in three flood events.

\section{ASSUMPTIONS}

Assumptions implicit in the use of equations 1 and 2 are:

i. The stream can be considered to be supplied by water of two types only (i.e. 'old' and 'new') and these have distinct isotopic signatures. 
ii. The isotopic compositions of the two types of water are constant or the variations are known.

iii. The isotopic composition of pre-event water entering the stream during the storm is the same as that of the baseflow immediately preceding the runoff event.

None of these assumptions is necessarily valid, so that estimates of stormwater volume may be in error. The assumption most likely to be invalid is (ii). Although pre-event (i.e. 'old') water comprises water of different residence times and isotopic concentrations, isotopic differences are generally greatly reduced as a consequence of mixing. However, considerable variation of the isotopic composition of rainfall can occur during individual storm events (McDonnell et al. 1990). In this study, it was not possible to collect samples during events and the $C_{n}$ values determined from daily bulk samples are volume weighted averages. This is acceptable if any temporal variability during a storm occurs randomly around the weighted average value, but will introduce error if there is a trend in the rainfall composition through the event. Studies in South Island, New Zealand report an average within-storm rain $\delta D$ range of $34 \%$ (standard deviation $=27$ ) for 17 events. In one event in which the $\delta D$ range in the rainfall was $32.9 \%$, volume weighted averaging over the whole storm overestimated the absolute contribution of 'new' water by between $14.5 \%$ and $10.7 \%$ in comparison to calculations based on different ways of averaging data collected incrementally through the storm (McDonnell et al., 1990). Since there is no way of knowing the temporal variability of the isotopic composition of rainfall within the storms sampled in this study, it is not possible to put definitive error bars on the results obtained. Nevertheless the possibility of errors of $\pm 10-20 \%$ in the absolute contribution of 'new' water to storm hydrographs, should be borne in mind throughout the remainder of this paper.

\section{Description of the study area}

\section{TOPOGRAPHY AND DRAINAGE}

The study catchment, located near the Grasslands Research Station, at Marondera, $70 \mathrm{~km}$ south-east of Harare (Fig. 1), forms the headwaters of the Manyame River. Catchment relief is low, with slopes less than $4 \%$ and altitude ranging from 1654 to 1611 metres above sea level. The catchment area is $3.33 \mathrm{~km}^{2}$. The stream channel starts approximately half-way along the length of the catchment, about $1 \mathrm{~km}$ from the gauging station.

The catchment comprises an upslope or interfluve region $2.12 \mathrm{~km}^{2}$ in area, and a dambo $1.21 \mathrm{~km}^{2}$ in area i.e. $36 \%$ of the catchment; areas were estimated from the tonal colour change on aerial photographs and from observations of soil moisture throughout the $1995 / 96$ wet season. The dambo extends the whole length of the catchment and incorporates a narrow spur on its northern slope which crosses the catchment boundary and joins another dambo in the neighbouring catchment (Fig. 1). The stream channel is incised into the dambo and consists of a number of interconnected pools, two to three metres deep and several metres across.

\section{GEOLOGY AND SOILS}

The catchment is underlain by Precambrian granite (Savory, 1964). Small outcrops (single residual core stones) scattered randomly within the catchment, indicate an irregular bedrock surface. Occasional intrusions of dolerite dykes within the catchment are typical of areas of Precambrian rock in Zimbabwe.

The catchment soils have been derived predominantly from the underlying granite, but in places texture and mineralogy reflect the influence of the dolerite dykes. A distinct catena exists on the slopes of the catchment; this is typical of the zonation seen in many catchments containing dambos (Fig. 2). The interfluve soils are acidic, strongly-leached and at an advanced stage of weathering. They are moderately deep coarse-to-medium grained ,loamy sands overlying sandy clay loams. The pedogenesis of the dambo soils has been influenced greatly by the extent and fluctuating pattern of waterlogging (Savory, 1964). The hydromorphic influence manifests itself in the accumulation of organic matter in the topsoils and gleying of subsoils. There is a well-defined clay wedge of irregular shape, embedded within a lens of sandy clay, at shallow depths within the dambo (Fig. 2). The clay and sandy clay act as a barrier, physically separating near-surface (i.e. above-clay) and deeper (i.e. below-clay) groundwater. However, the clay is discontinuous so that the two aquifers are to a large extent in hydraulic continuity. The soil profile over much of the dambo is saturated in the wet season because vertical drainage is impeded by the heavy textured subsoils and the low slope angle reduces throughflow efficiency. The infiltration capacities of surface soil on both the interfluve and the dambo are high and exceed 10minute duration rainfall rates with return periods of up to 30 years. Consequently, Hortonian overland flow occurs only rarely within the catchment.

\section{CLIMATE}

The climate is largely dependent on the movement of airmasses within the Intertropical Convergence Zone (ITCZ). Rainfall occurs predominantly during the summer (October to April) whilst the winter months (May to September) are usually dry. Annual rainfall varies considerably from year to year but the long-term average (1956 to 1995), determined at the Grasslands Meteorological Station (located less than $1.5 \mathrm{~km}$ from the catchment) is $859 \mathrm{~mm}$. During the winter, the mean temperature is about $12.5^{\circ} \mathrm{C}$, although night temperatures sometimes drop below freezing. During the summer, mean temperature is $18.4^{\circ} \mathrm{C}$. Average annual potential 


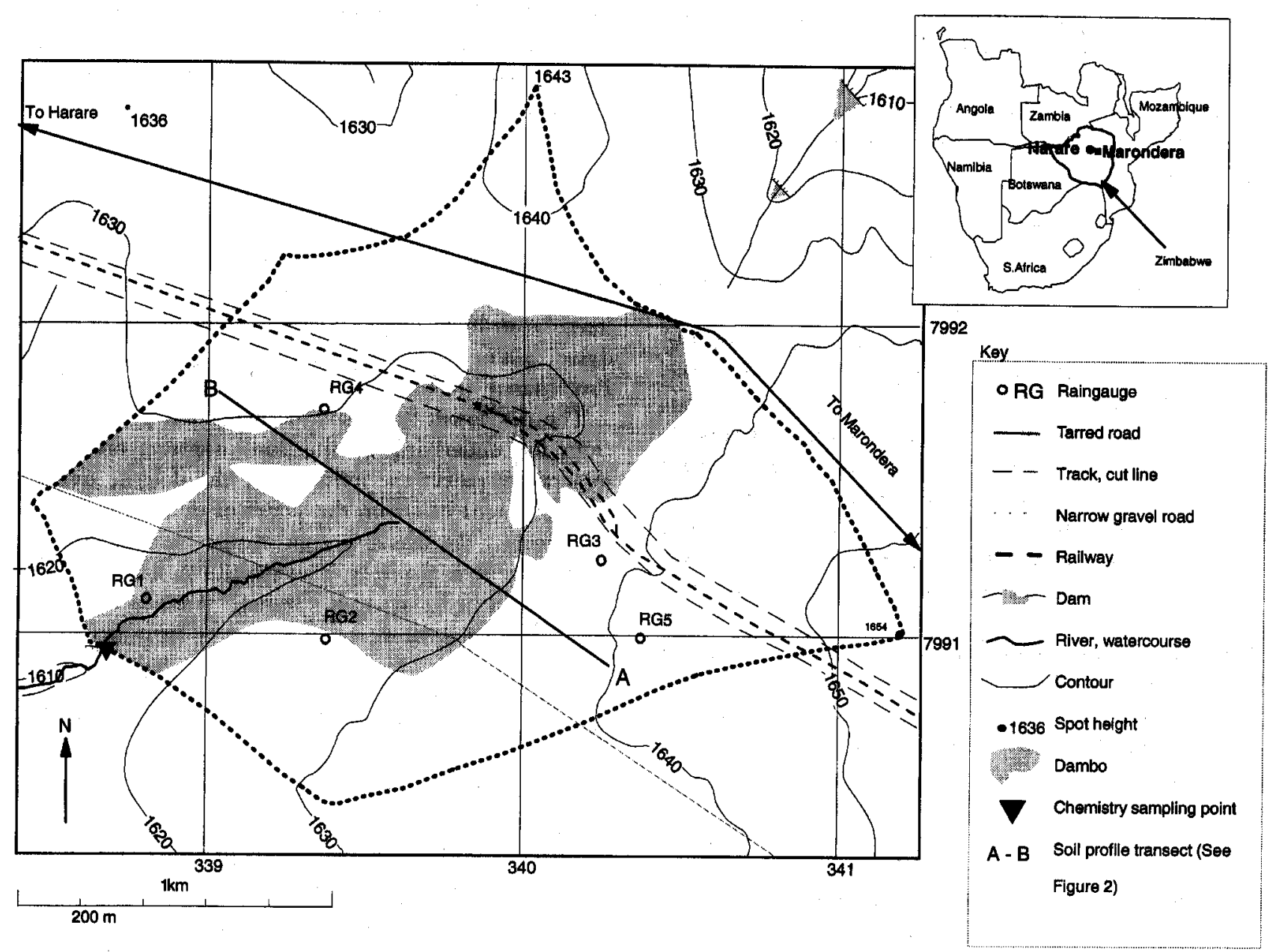

Fig. 1. The Grasslands Research Catchment.

evapotranspiration, as estimated by the Penman approach (Penman, 1948), is $1700 \mathrm{~mm}$.

\section{VEGETATION AND LAND-USE}

As in most catchments containing dambos, the vegetation changes in character from the interfluve to the dambo. There are areas of miombo (Brachystegia speciformis) and mixed woodland on the interfluve, while on the dambo various species of grass predominate. The catchment is used primarily for light cattle grazing although there is some cultivation of maize. The main road and railway line from Harare to Mutare pass through the eastern end of the catchment: both are on raised banks through which water is transmitted via culverts.

\section{FLOW REGIME}

Stream discharge has been measured since 1956 by the Hydrological Branch of Zimbabwe at a weir built across a granite outcrop at the catchment outlet. The weir is a com- pound structure consisting of a $45^{\circ} \mathrm{V}$-notch and six rectangular angle-iron crests. Stage is recorded continuously with a chart recorder. Flow is ephemeral and ceases during the dry winter months each year. Typically, in years with less than about $500 \mathrm{~mm}$ of rain, there is no flow from the catchment. Table 1 presents summary statistics of the catchment runoff for the period 1956 to 1995 , which contained three years with zero flow.

\section{Hydrometric and chemical monitor- ing and data processing}

Monitoring was conducted from October 1995 until flow from the catchment ceased in early September 1996.

\section{PRECIPITATION, STREAMFLOW AND WATERTABLE}

The Thiessen Polygon method (Thiessen, 1911) was used to derive daily averages of catchment rainfall from daily readings from five raingauges within the catchment. Daily 
Table 1. Summary statistics of annual runoff from the Grasslands Research Catchment (1956-1995) at Marondera, Zimbabwe.

\begin{tabular}{cccccccc}
\hline $\begin{array}{c}\text { Mean annual } \\
\text { rainfall } \\
\mathrm{mm}\end{array}$ & $\begin{array}{c}\text { Mean annual } \\
\text { runoff } \\
\text { \%m rainfall }\end{array}$ & year & $\begin{array}{c}\text { runoff } \\
\mathrm{mm}\end{array}$ & $\%$ rainfall & mm & \multicolumn{2}{c}{$\begin{array}{c}\text { Minimum annual } \\
\text { runoff }\end{array}$} \\
\hline 859 & 86 & 10 & 1980 & 506 & 30 & 0.0 & 0 \\
\hline
\end{tabular}

values were disaggregated to 10 -minute resolution using data from an autographic raingauge at the Grasslands Meteorological Station.

Hourly values of flow were obtained from commencement of flow on $12 / 12 / 95$ until it ceased on $05 / 09 / 96$ by digitising the stage charts. Stage was also measured manually through storm events in which stream samples were collected for chemical analysis (see below). Levels were converted to flow using a theoretical rating validated by dilution gauging.

The depth to the watertable was measured daily in sixteen dipwells installed along transect A-B (Fig. 1). The dipwells, installed either to bedrock or to a depth of $6 \mathrm{~m}$, were perforated over their entire length. All those located on the dambo penetrated through the clay lens.

\section{SAMPLING FOR HYDROCHEMICAL ANALYSES}

Rainwater was collected for $\mathrm{pH}$, Gran-alkalinity (determined by acidimetric titration over a $\mathrm{pH}$ range 3.0 to 4.0 ), conductivity and chloride analysis when the daily catch in any of the five raingauges in the catchment exceeded 10 $\mathrm{mm}$. Water was also taken from a copper storage gauge at the Grasslands Meteorological Station when catches there were greater than $10 \mathrm{~mm} .100 \mathrm{ml}$ 'grab' samples were collected in glass bottles from the flow passing over the crest of the weir at the catchment outlet. Measurements were made for almost the entire period that flow occurred in 1995/96; samples were collected daily from the day after flow commenced (13/12/95) until 14/06/96, and thence twice weekly until $29 / 08 / 96$. More frequent flow samples were collected during three storm events in January and February 1996. Prior to analysis, samples were stored in glass McCartney bottles. For sample collection and for storage, the waters collected were kept in filled bottles to negate isotopic changes associated with water evaporation.

\section{LABORATORY ANALYSIS}

Filtered samples were analysed for deuterium following reduction to hydrogen gas over heated zinc. Measurement was performed using a VG Optima mass spectrometer in the IH stable isotope laboratory at Wallingford using standard methodologies (Darling et al., 1992). One repeat experiment indicates that analytical precision for $\delta D$ was $\pm 2 \%$ o.

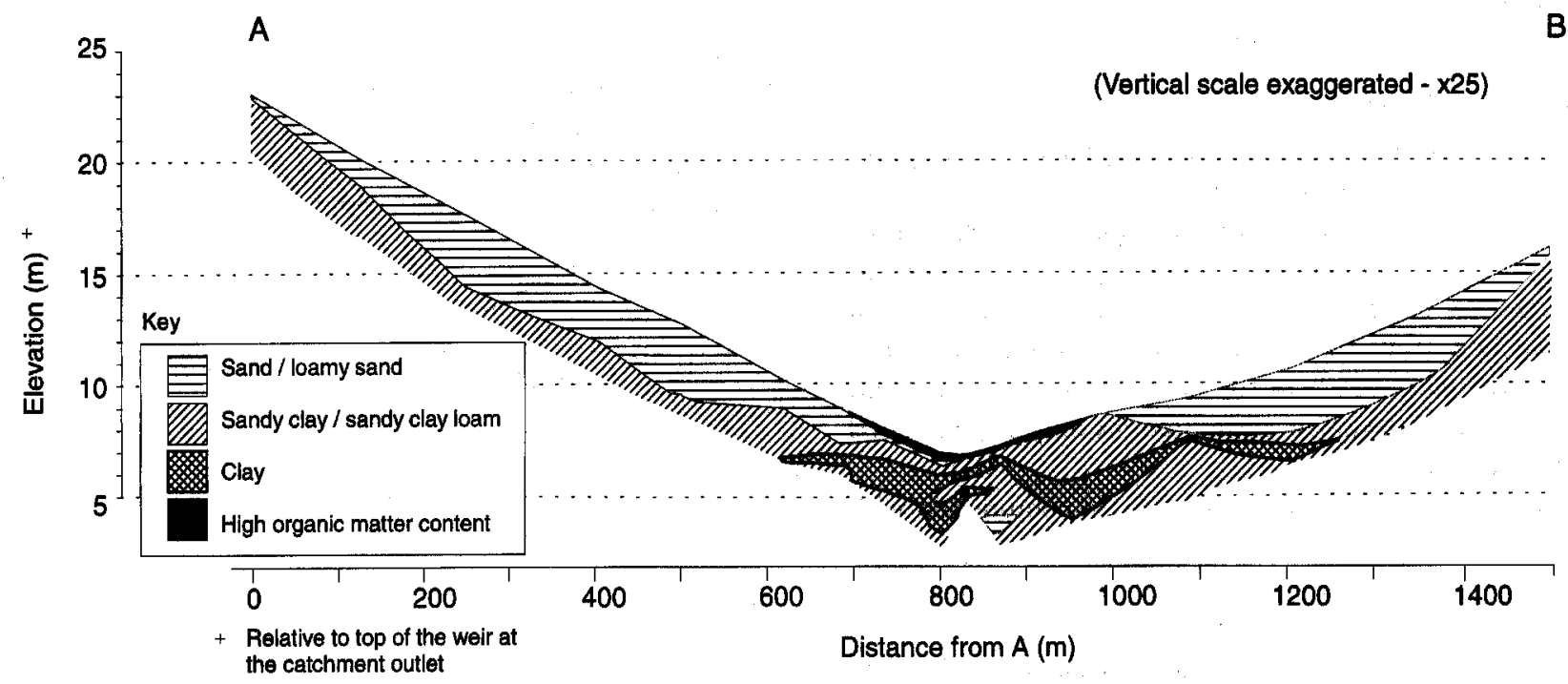

Fig. 2. Cross-section showing the soil profile in the main transect $A B$. 


\section{HYDROGRAPH SEPARATION}

Hydrograph separation, using the method outlined above, was conducted for three events on 26/01/96, 09/02/96 and 28/02/96. $C_{n}$ was determined as the average value measured in the water samples collected from the raingauges in the catchment and at the Meteorological Station. The isotopic composition of the rainfall was assumed to be unvarying through an individual storm event. $C_{0}$ was taken to be the measured concentration in the stream water prior to the event. Equations 1 and 2 were solved for each occasion on which stream water samples were collected over a storm hydrograph. The magnitude of the flow components between sampling times was estimated by linear interpolation, and the contribution of 'new' and 'old' water to total streamflow was computed by summing across the stormflow period.

\section{Results}

\section{HYDROLOGY}

During 1995/96, the catchment average rainfall (1085 $\mathrm{mm})$ was significantly above the long-term average ( 859 $\mathrm{mm}$ ). Despite this, streamflow was just $99 \mathrm{~mm}$ averaged over the catchment area (i.e. $9.1 \%$ of the rainfall). In 1995, the catchment required significant wetting-up at the start of the rainy season and $315 \mathrm{~mm}$ of rain fell before any flow was measured at the weir. Although the first rain fell on $21 / 10 / 95$, there was no flow from the catchment until $12 / 12 / 95$. Flow continued until 05/09/96 (i.e. 269 days), From mid-January to early April, the watertable was either at, or just a few centimetres below, the ground surface over a large part of the dambo. Figure 3 compares the watertable across the transect (shown in Fig. 1) on $30 / 10 / 95$, just after the start of the rainy season, and on two occasions $(26 / 01 / 96$ and $09 / 02 / 96)$ when storm hydrographs were sampled.

Once the dambo was saturated, surface runoff flowed continually along the valley bottom into the head of the stream channel. Macropore flow moving above the clay lens also entered the channel at this point. Throughout this period, the catchment was highly responsive to rainfall. Of the total flow, $82 \%(81.2 \mathrm{~mm})$ occurred in January $(52.9 \mathrm{~mm})$ and February $(28.3 \mathrm{~mm})$. Frequency analysis indicates that the flow on 23 days accounted for $77 \%$ of the total flow from the catchment and the flow on just 3 days accounted for $36 \%$ of the total. Although continuous until September, baseflow accounted for only $10 \%$ of total streamflow.

Analysis of the Gran-alkalinity data, in conjunction with groundwater levels (to be reported in detail in a later paper) indicates that flow in the catchment was dominated by shallow throughflow and surface runoff. Dry season recession flows originate from slow drainage of shallow (i.e. above-clay) soils only and there is no evidence that water from below the clay lens contributed significantly to flow at any time.

\section{ISOTOPIC TIME SERIES DATA}

Deuterium varied in time for both rainfall and stream water in the range -160 to $+13 \%$ (Fig. 4a) and shows similar patterns of behaviour. As a consequence of a rainfall event, $\delta D_{\text {stream }}$ often changed sharply in either the positive or the negative direction depending on whether the $\delta D_{\text {rain }}$ was more or less negative than $\delta D_{\text {stream }}$ prior to the event. On the hydrograph recessions, $\delta D_{\text {stream }}$ tended to change gradually back towards its pre-event value. The high rainfall event (24-hour catchment average rainfall was $109 \mathrm{~mm}$ ) on 15/01/96 (day 107 after $01 / 10 / 95$ ) resulted

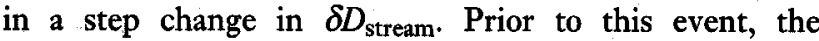
watertable reached the ground surface only in the region immediately in the vicinity of the stream channel. After it, the soil profile was saturated across almost the whole extent of the dambo. During the long dry season recession from mid-April (day 198), $\delta D_{\text {stream }}$ changed only very slightly from day to day. Following unseasonally heavy rainfall at the end of May (days 233 to 243 after $01 / 10 / 95), \delta D_{\text {stream }}$ increased very gradually, indicating that, as the dry season progressed, water in the recession flow was enriched in heavier water molecules as a consequence of evaporation.

Linear regression was used to investigate the link between the rainfall signal (i.e. 'new' water) and the consequent signal observed in the stream water. Data from the entire 1995/96 wet season gives the relationship (significant at the $\alpha=0.001$ level) (Fig. 4b):

$$
\begin{gathered}
\delta D_{\text {stream }}=0.626( \pm 0.187) \delta D_{\text {rain }}-12.59( \pm 41.70) \\
R^{2}=0.63 \quad n=29
\end{gathered}
$$

where terms in parentheses refer to twice the standard error.

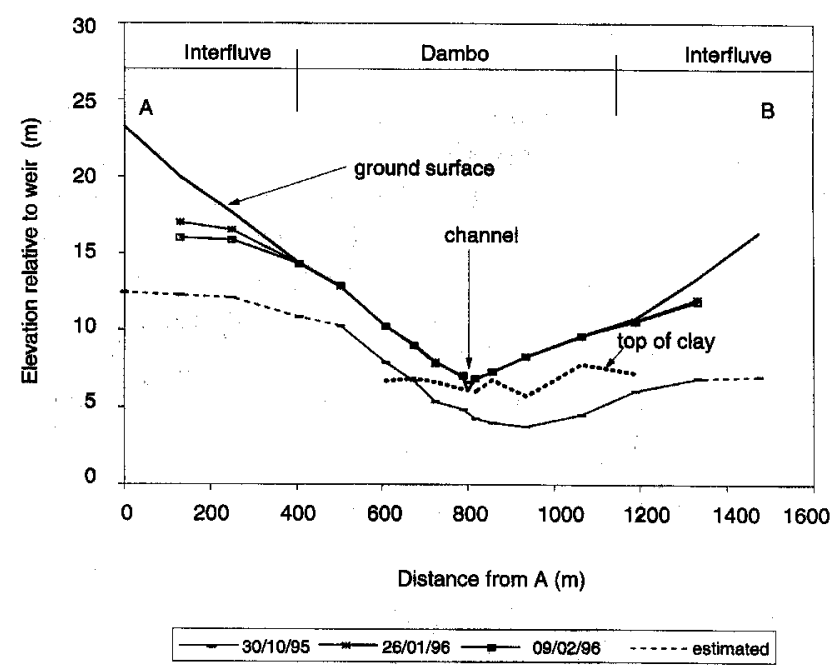

Fig. 3. Watertable across the transect $A B$. 


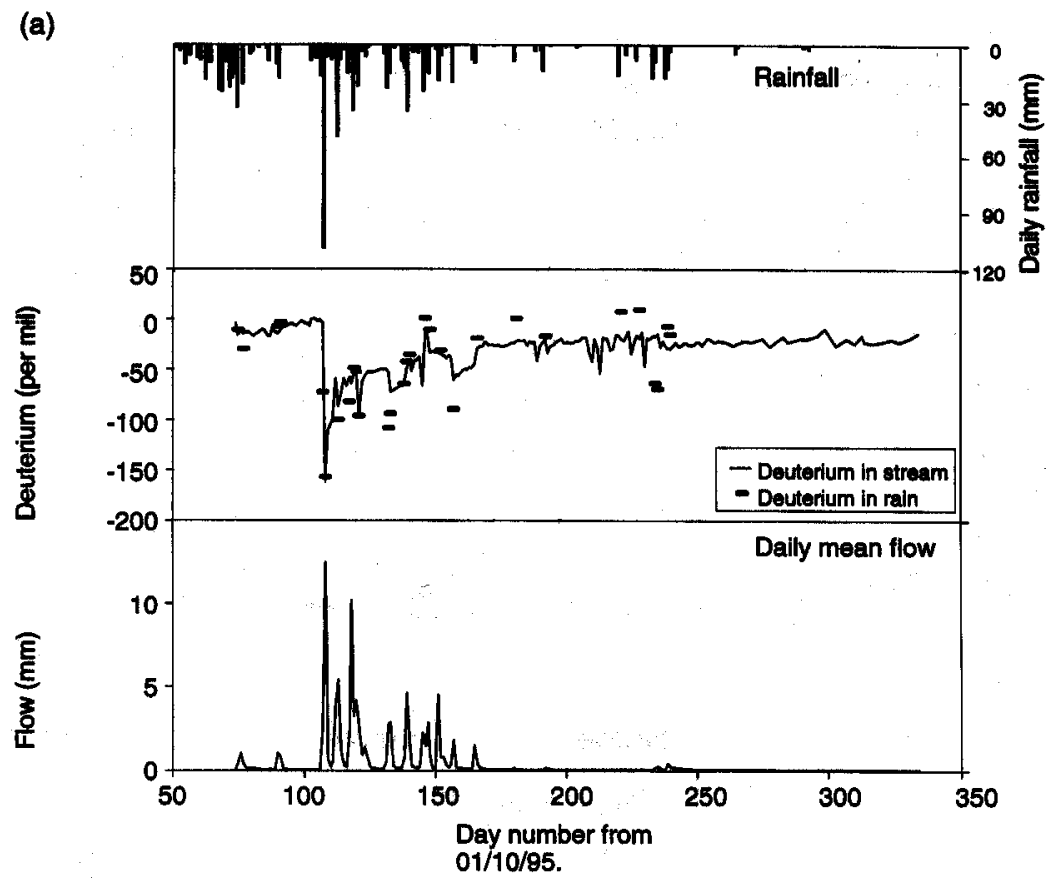

(b)

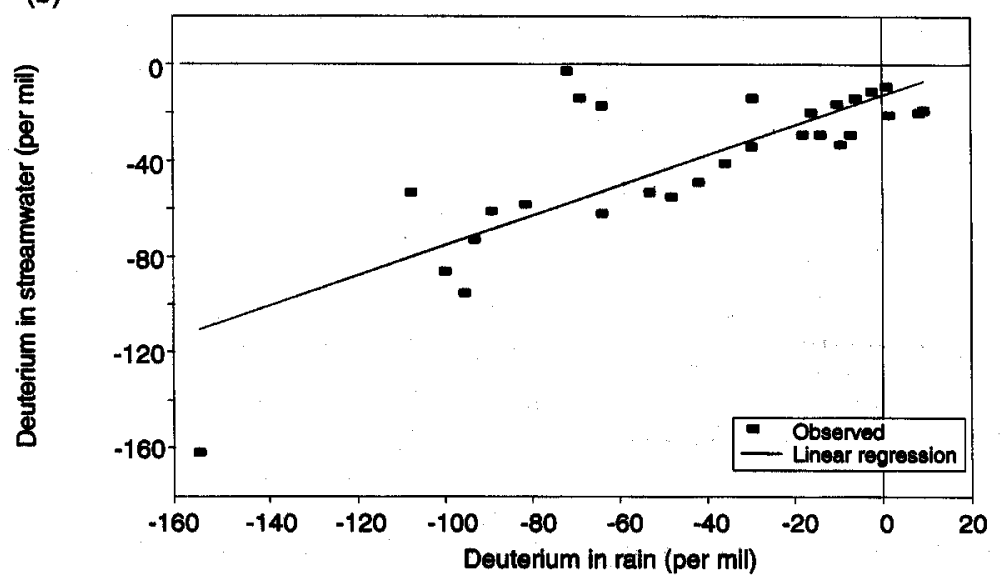

Fig. 4. Deuterium in stream water and rain a) time series b) linear regression.

This includes rainfall events in December and in May when the catchment was drier. If the regression analysis is repeated for the period when the catchment was at its wettest i.e. from $16 / 01 / 96$ (day 108 after $01 / 10 / 95$ ) to 9/04/96 (day 192 after 01/10/95), the relationship between the rainfall and stream water signals remains significant (at the $\alpha=0.001$ level), but the amount of variance explained is greater:

$$
\begin{gathered}
\delta D_{\text {stream }}=0.722( \pm 0.172) \delta D_{\text {rain }}-13.69( \pm 30.96) \\
R^{2}=0.82 \quad n=18
\end{gathered}
$$

This illustrates the sensitivity to antecedent conditions of the catchment response to rainfall. When the catchment is wet, the rainfall signal is highly correlated with the streamflow signal, indicating the rapid transfer of rainwater to the stream. However, when the catchment is drier, less rain- fall is delivered to the stream, so the correlation between $\delta D_{\text {rain }}$ and $\delta D_{\text {stream }}$ decreases. Thus, the greater the soil moisture deficit, the weaker the link between the rainfall and streamflow signals.

\section{ISOTOPIC HYDROGRAPH SEPARATION}

Temporal variation in streamflow signal through events was used to quantify the proportion of 'new' and 'old' water in event hydrographs. Hydrograph separation techniques were attempted for three events. However, in the event on 28/02/96 the isotopic compositions of rainwater and pre-event stream water were insufficiently distinct for meaningful results to be obtained and this event was discounted for hydrograph separation: in this case the difference was just $2 \%$ (i.e. within the $\pm 2 \%$ error of deter- 
(a)

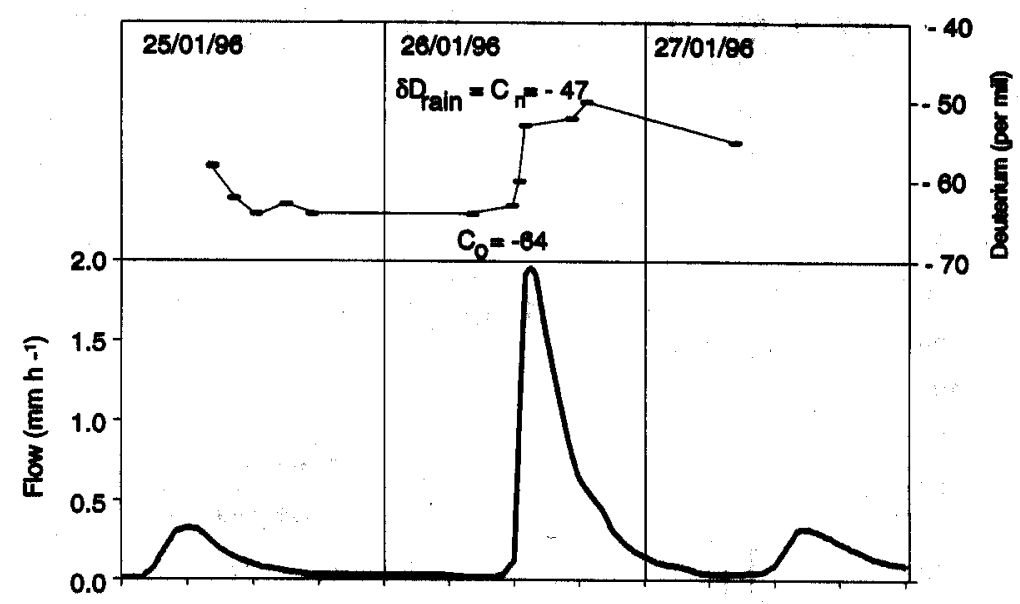

(b)

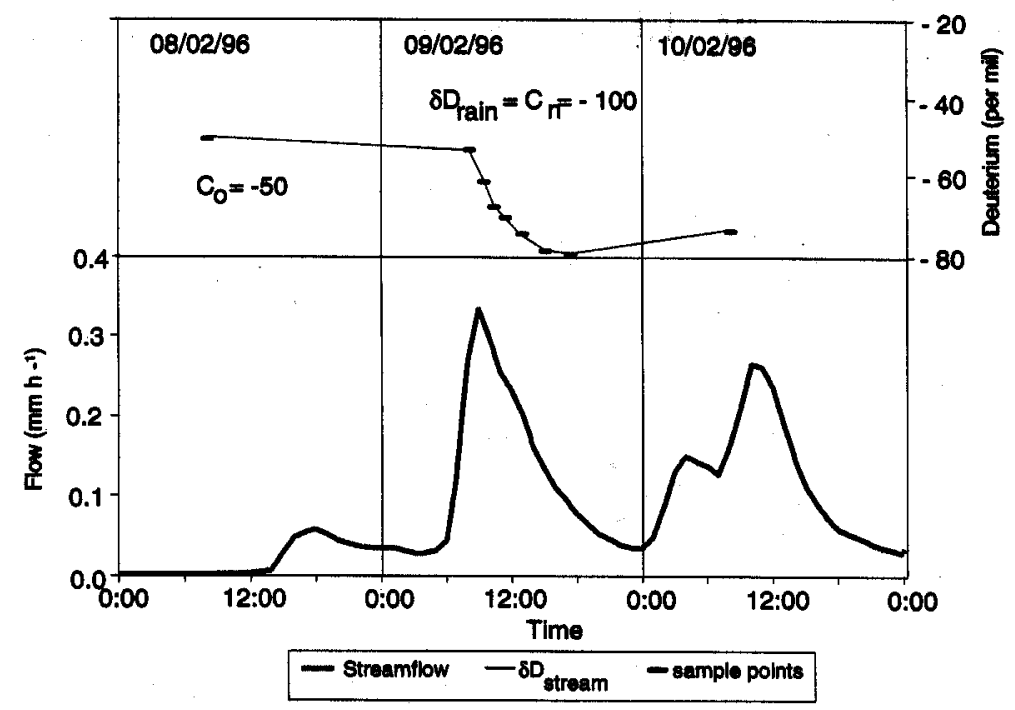

Fig. 5. Variation in deuterium and flow a) $25 / 01 / 96$ to $27 / 01 / 96$ b) $08 / 02 / 96$ to $10 / 02 / 96$.

mination) but Bonell et al. (1990) recommend that a difference of $>15 \%$ in $\delta D$ is required for hydrograph separation.

The flow characteristics of the two events for which hydrograph separation was successful are summarised in Table 2. The peak flow on $26 / 01 / 96$ was the highest instantaneous flow measured in the $1995 / 96$ wet season. There were 16 events in 1995/96 with peak flows exceeding $0.2 \mathrm{~mm} \mathrm{~h}^{-1}$. The event on $09 / 02 / 96$ was the eighth largest and so it can be considered the median event.

Figure 5 shows the change in discharge and the corresponding change in the deuterium signal through the two

Table 2. Storm hydrograph separations into 'old' and 'new' water using deuterium

\begin{tabular}{cccccccccc}
\hline Event & $\begin{array}{c}\text { Rainfall } \\
\mathbf{P} \\
(\mathrm{mm})\end{array}$ & $\begin{array}{c}\text { Total } \\
\text { flow, QToT } \\
(\mathrm{mm})\end{array}$ & $\begin{array}{c}\text { Peak } \\
\text { flow } \\
\left(\mathrm{mm} \mathrm{h}^{-1}\right)\end{array}$ & $\begin{array}{c}\text { Time to } \\
\text { peak } \\
(\mathrm{hrs})\end{array}$ & $\begin{array}{c}\text { Rank* } \\
\text { Contribution to total flow } \\
\text { 'old' }\end{array}$ & $\begin{array}{c}\text { 'new' } \\
\text { water } \\
\mathrm{Q}_{0}(\mathrm{~mm})\end{array}$ & $\begin{array}{c}\text { water } \\
\mathrm{QN}_{\mathrm{N}}(\mathrm{mm})\end{array}$ & $\begin{array}{c}\text { (\%) } \\
(\%)\end{array}$ & $\begin{array}{c}\mathrm{Q}_{\mathrm{N}} / \mathrm{Q}_{\mathrm{TOT}} \\
(\%)\end{array}$ \\
\hline $26 / 01 / 96$ & 35.1 & 10.63 & 1.97 & 3.5 & 1 & 3.17 & 7.46 & 21.3 & 70.2 \\
$09 / 02 / 96$ & 18.6 & 2.66 & 0.33 & 4.8 & 8 & 1.74 &, 0.92 & 4.95 & 34.7 \\
\hline
\end{tabular}

\footnotetext{
* Rank position of peak flow for $1995 / 96$ events.
} 
Table 3. Timing and maximum proportion of flow occupied by 'new' water

\begin{tabular}{|c|c|c|c|c|c|c|c|c|c|}
\hline \multirow[b]{2}{*}{ Event } & \multirow[b]{2}{*}{$\begin{array}{l}\text { Peak flow } \\
\left(\mathrm{mm} \mathrm{h}^{-1}\right)\end{array}$} & \multirow[b]{2}{*}{ Time } & \multicolumn{3}{|c|}{$\begin{array}{l}\text { Point at which 'new' water } \\
\text { becomes majority of discharge }\end{array}$} & \multicolumn{4}{|c|}{$\begin{array}{l}\text { Maximum proportion of discharge } \\
\text { occupied by 'new' water }\end{array}$} \\
\hline & & & $\begin{array}{l}\text { Hydrograph } \\
\text { limb }\end{array}$ & Time & $\begin{array}{c}\text { Flow } \\
\left(\mathrm{mm} \mathrm{h}^{-1}\right)\end{array}$ & $\begin{array}{l}\text { Qo } \\
\%\end{array}$ & $\begin{array}{l}\mathrm{QN}_{\mathrm{N}} \\
\%\end{array}$ & Time & $\begin{array}{c}\text { Flow } \\
\left(\mathrm{mmh}^{-1}\right)\end{array}$ \\
\hline $26 / 01 / 96$ & 1.97 & $13: 30$ & rising & $12: 50$ & 1.62 & 12.5 & 87.5 & $18: 40$ & 0.57 \\
\hline $09 / 02 / 96$ & 0.33 & 09:00 & recession & $13: 40$ & 0.18 & 42.0 & 58.0 & $17: 30$ & 0.09 \\
\hline
\end{tabular}

storm events. In both events the composition of the storm runoff indicates a mixing of 'new' (current event) and 'old' (pre-event) water (Fig. 6; Table 2) with 'new' water forming a substantial proportion of total flow. In the two events of $26 / 01 / 96$ and $09 / 02 / 96$, 'new' water formed $70.2 \%$ and $34.7 \%$ of the stormflow, and the maximum instanta- neous 'new' water contributions were $87.5 \%$ and $58.0 \%$, respectively. In both events, the largest proportion of 'new' water occurred in the recession phase of the hydrograph (Table 3). Only in the event on 26/01/96 did 'new' water start to dominate on the rising limb. The results indicate, reasonably, that the larger the event, the greater

(a)

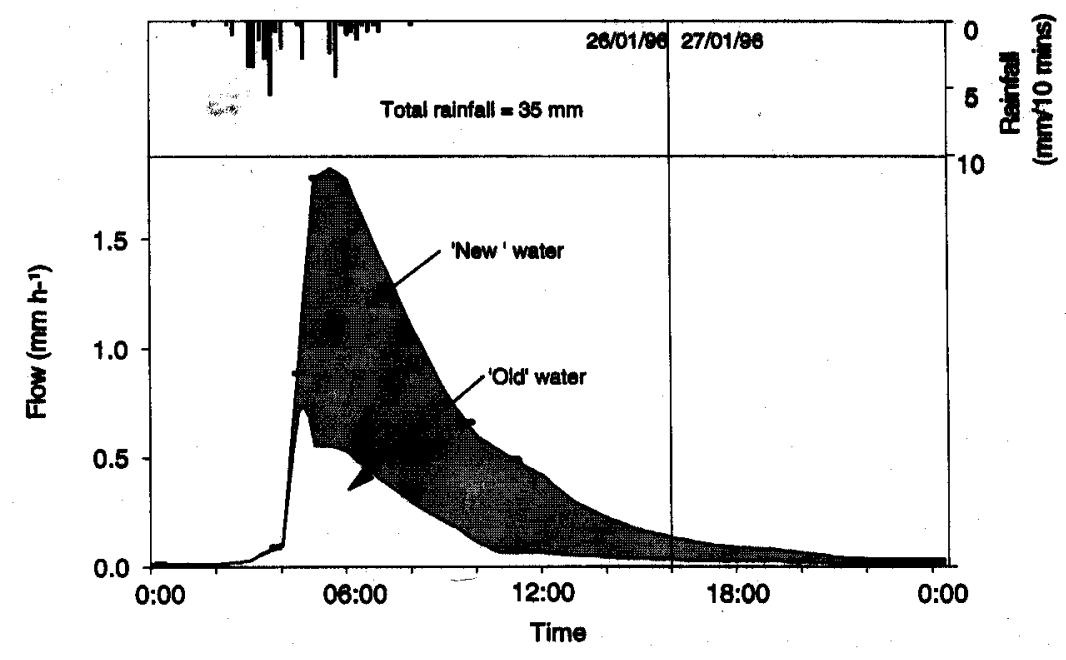

(b)

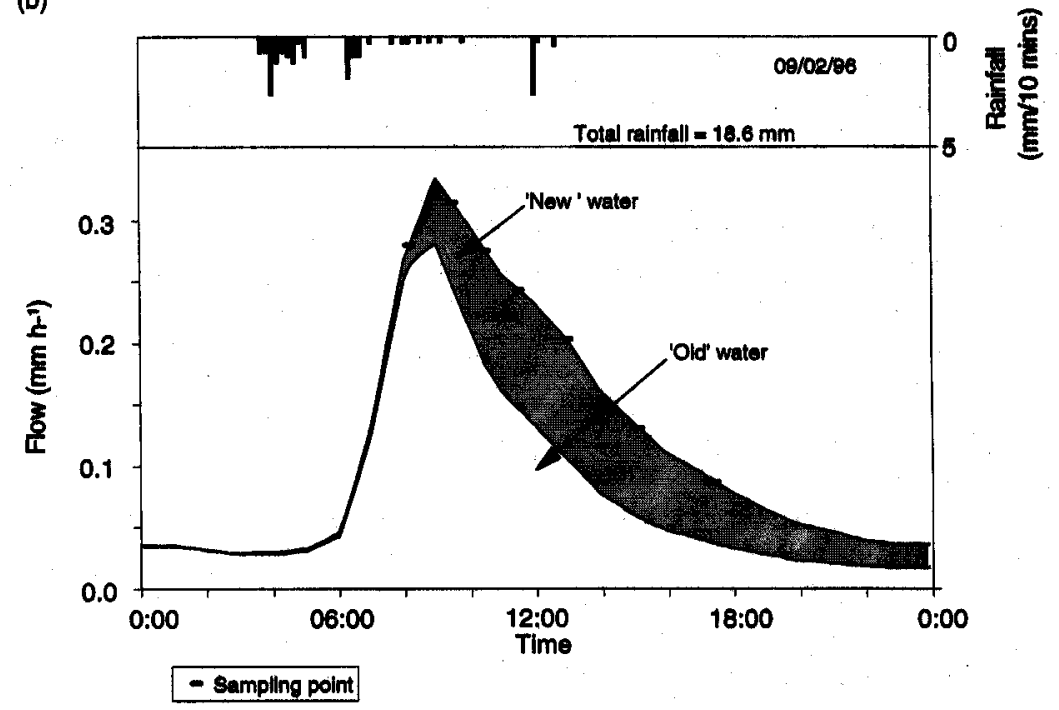

Fig. 6. Storm hydrograph separation using deuterium a) 26/01/96 b) 09/02/96. 
the proportion of 'new' water in the storm hydrograph, and the more rapid the transfer of 'new' water to the stream.

\section{Discussion}

\section{DAMBO RAINFALL-RUNOFF RELATIONSHIPS}

The high degree of correlation between the deuterium signals of rainfall and stream water, once the dambo is saturated, indicates the fast response and short residence time of storm runoff during these conditions. The only way these observations can be explained is to invoke fast flowpaths which transmit 'new' water rapidly to the stream.

For the hydrographs on $26 / 01 / 96$ and $09 / 02 / 96$, the volumes of 'new' water comprised $58.0 \%$ and $13.6 \%$ of the rainfall onto the dambo, respectively. In terms of total 'new' water contributions to storm hydrographs, these results are similar to those obtained by Sandström (1996) in Tanzania. However, the catchment topography and vegetation are very dissimilar, and the proposed runoffgenerating mechanism is different. Unlike in the Tanzania study, Hortonian overland flow is very rare in the Grasslands Research Catchment in Zimbabwe. Instead, it is hypothesised, supported by field observation, that saturation overland flow, generated solely within the area of the dambo, is the major mechanism of storm runoff production in the catchment.

On 26/01/96 and 09/02/96, antecedent conditions within the catchment were similar and the watertable was either at or very close to the ground surface over much of the dambo on both days (Fig. 3). Consequently, the difference in catchment response between the two events can be attributed to the greater amount of rain and the much higher intensities in the event on 26/01/96 compared to that on $09 / 02 / 96$. In the first event, the rainfall total was almost twice that of the second, and the maximum 10-minute intensity was $32.4 \mathrm{~mm} \mathrm{~h}^{-1}$, compared to $17.4 \mathrm{~mm} \mathrm{~h}^{-1}$ in the second event. This resulted in a greater discharge volume, a shorter time to peak and much greater contributions of 'new' water in the first event (Table 2).

The relationship between storm characteristics and 'new' water contributions to stormflow suggests that the response across the dambo varies over short time periods. Within the dambo, where the soil profile is not completely saturated, the closeness of the perched watertable to the ground surface probably ensures that the capillary fringe (i.e. the region above the watertable which is under tension but remains close to saturation) will extend to the surface. Under such circumstances, application of only a small amount of water can result in a large and rapid rise of the watertable (Jayatilika and Gillham, 1996), and the extent of expansion of the saturated region will be very sensitive to the amount and, to a lesser extent, to the intensity of rainfall.

\section{'OLD' AND 'NEW' WATER COMPONENTS IN STORM HYDROGRAPHS}

Stream hydrographs with total 'new' water contributions varying from $28.0 \%$ to $53.5 \%$ and maximum instantaneous discharges of 'new' water between $40.0 \%$ and $80.0 \%$ have been noted during large storms in a New Zealand headwater catchment containing a valley bottom wetland that comprised $20 \%$ of the catchment (Bonell et al., 1990). Similar findings have been reported in a study of a riparian wetland comprising just $2 \%$ of a moraine headwater catchment in Canada (Hill and Waddington, 1993). Total 'new' water contributions to storm hydrographs varied from $11.0 \%$ to $41.0 \%$, and instantaneous contributions varied from $19.5 \%$ to $63.0 \%$. Direct comparison of these studies is difficult because of the different environments in which these wetlands exist. However, these results indicate that runoff-generating mechanisms within the catchments are probably similar and, as a general approximation, the greater the proportion of wetland within the catchment, the larger both the total and instantaneous maximum contribution of 'new' water to storm hydrographs.

Studies in temperate catchments without wetlands have shown that 'old' water comprises a greater proportion of the total discharge in most storm hydrographs and stream responses to isotopic variations in rainwater are usually damped. Typically, maximum instantaneous 'new' water contributions vary between $8 \%$ and $40 \%$ (e.g. Sklash and Farvolden, 1979; Sklash et al., 1986; Neal et al., 1992; 1996). Durand et al. (1993) report instantaneous 'new' water contributions of up to $54 \%$ in a mountainous grassland catchment in south-eastern France. However, this results from an intense rainfall of $90 \mathrm{~mm}$ in a few hours and, although not stated, may have resulted from Hortonian overland flow.

\section{THE OVERALL ROLE OF DAMBOS IN RUNOFF GENERATION AND STORAGE}

It is difficult to reconcile the findings of this study with those of some previous researchers who have reported that dambos attenuate flood flows. However, the hydrograph separation was conducted on two events, both of which occurred when the watertable was at the surface across much of the dambo. The regression analysis indicated that the catchment response is sensitive to antecedent conditions. It is therefore surmised that, in terms of flow generation, dambos play a dual role by promoting water storage prior to saturation and, once saturated, by promoting rapid overland flow.

Support for the hypothesis that dambos may store more water than elsewhere in a catchment prior to saturation comes from drainage experiments conducted in Zimbabwe (Twomlow, 1994). These experiments showed that sand required $30-40 \mathrm{~mm}$ of rain and a clay loam $90 \mathrm{~mm}$ of rain, to wet the top $50 \mathrm{~cm}$ of an initially dry soil profile to field 
capacity; at saturation, the water content in a $90 \mathrm{~cm}$ profile was $247 \mathrm{~mm}$ in the sand and $464 \mathrm{~mm}$ in the clay loam. These results indicate that, in comparison with sandier soils, the heavier dambo soils will absorb and retain greater quantities of water, an effect that will be enhanced by their relatively high organic matter content. The seasonallyvarying response of hydromorphic soils to rainfall events is confirmed by runoff generation data from different studies collated by Dubreuil (1985); on hydromorphic vertisols, the minimum rainfall required to generate runoff at the beginning of the wet season is greater than that required in the middle and at the end of the rainy season, when saturated conditions are achieved.

\section{Concluding remarks}

The isotope study conducted at the Grasslands Research Catchment at Marondera, Zimbabwe has provided an insight into the runoff-generating mechanisms occurring within a headwater catchment containing a dambo. The results obtained are consistent with observations made in wetland catchments in temperate climates; they indicate that, once saturated, the catchment response is sensitive to the rainfall characteristics and the dambo acts as a source of overland flow. It is postulated that dambos play a dual role in the production of stormflow, by (a) increasing storage and thus reducing runoff prior to saturation, and (b) promoting runoff once the watertable reaches the ground surface across the dambo.

\section{Acknowledgements}

The authors are indebted to Andrew Bullock and Helen Houghton-Carr of the Institute of Hydrology for very helpful comments on earlier versions of this paper; to the staff of the Horticultural Research Centre at Marondera, Luckmore Chigwaze and Samson Muswere in particular, for their assistance with fieldwork; to James Dodd who carried out the deuterium analyses and Val Bronsdon who produced the figures. The Hydrological Branch and Meteorological Department of Zimbabwe provided hydrometeorological data. This work was funded by the UK Natural Environment Research Council.

\section{References}

Balek, J. and Perry, J.E. 1973. Hydrology of seasonally inundated African headwater swamps. 7. Hydrol., 19, 227-249.

Bonell, M., Pearce, A.J., Stewart, M.K. 1990. The identification of runoff-production mechanisms using environmental isotopes in a tussock grassland catchment, Eastern Otago, New Zealand. Hydrol. Processes., 4, 15-34.

Bullock, A. 1992. The role of dambos in determining river flow regimes in Zimbabwe. 7. Hydrol., 134, 349-372.

Clark, I. and Fritz, P. 1997. Environmental Isotopes in Hydrogeology. Lewis Publishers, New York. pp. 328.

Darling, W.G., Talbot, J.C., Warrington, A.G. 1992. Current procedures for the measurement of ${ }^{2} \mathrm{H} /{ }^{1} \mathrm{H}$ and ${ }^{18} \mathrm{O} /{ }^{16} \mathrm{O}$ in water samples. British Geological Survey. Report No. WD/92/11, pp. 22.

Drayton, R.S., Kidd, C.H.R., Mandeville, A.N. and Miller, J.B. 1980. A regional analysis of river floods and low flows in Malawi. Institute of Hydrology. Report No. 72. pp. 79, Wallingford, UK.

Dubrueil, P.L. 1985. Review of field observations of runoff generation in the tropics. 7. Hydrol., 80, 237-264.

Dubrueil, P.L. 1986. Review of relationships between geophysical factors and hydrological characteristics in the tropics. 7 . Hydrol., 87, 201-222.

Durand, P., Neal, M. and Neal, C. 1993. Variations in stable oxygen isotope and solute concentrations in small submediterranean montane streams. F. Hydrol. 144, 283-290.

Hill, A.R. and Waddington, J.M. 1993. Analysis of storm run-off sources using oxygen-18 in a headwater swamp. Hydrol. Processes., 7, 305-316.

Jayatilaka, C.J. and Gillham, R.J. 1996. A deterministic-empirical model of the effect of the capillary fringe on near-stream area runoff, 1. Description of the model. 7. Hydrol., 184, 299-315.

Kanthack, F.E., 1945. Relationships between rainfall and runoff in central southern Africa. Proc. S. Afr. Soc. Civil Eng., 43, $29-48$.

Mackel, R. 1974. Dambos: a study of morphodynamic activity on the plateau regions of Zambia. Catena, 1, 327-365.

McDonnell, J.J., Bonell, M., Stewart, M.K. and Pearce, A.J. 1990. Isotopic variations in storm rainfall: Implications for stream hydrograph separation. Wat. Resour. Res., 26, 455-458

Neal, C. Neal, M., Warrington, A., Avila, A., Pinol, J. and Roda, F. 1992. Stable hydrogen and oxygen isotope studies of rainfall and stream waters for two contrasting holm oak areas of Catalonia, north eastern Spain. 7. Hydrol., 140, 163-178.

Neal, M., Neal, C. and Brahman, G., 1996. Stable oxygen isotope variations in rain, snow and stream waters at the Schluchsee and Villingen sites in the Black Forest, SW Germany. 7. Hydrol. 190, 102-110.

Pearce, A.J., Stewart, M.K. and Sklash, M.G. 1986. Storm runoff generation in humid headwater catchments 1 . Where does all the water come from? Wat. Resour. Res. 22, 1263-1272.

Penman, H.L. 1948. Natural evaporation from open water, bare soil and grass. Proc. Roy. Soc. Lond. A, 193, 120-145.

Sandström, K. 1996. Hydrochemical deciphering of streamflow generation in semi-arid East Africa. Hydrol. Processes 10, 703-720.

Savory, R.M. 1964. The relationship of matertable levels to soil development in a granite vlei at Marandellas, Southern Rhodesia. MSc. Thesis University of London. pp. 121.

Sklash, M.G. and Farvolden, R.N. 1979. The role of groundwater in storm runoff. 7 . Hydrol., 43, 45-65.

Sklash, M.G., Stewart, M.K. and Pearce, A.J. 1986. Storm runoff generation in humid headwater catchments II: a case study of hillslope and low order stream response. Wat. Resour. Res., 2, 1273-282.

Thiessen, A.H. 1911. Precipitation for large areas. Mon. Weath. Rev. 39, 1082-1084.

Twomlow, S.J. 1994. Field moisture characteristics of two fersiallitic soils in Zimbabwe. Soil Use Manag., 10, 168-173.

Ward, R.C. 1984. On the response to precipitation of headwater streams in humid areas. F. Hydrol., 74, 171-189. 
Wels, C. Cornett, R.J. and Lazerete, B.D. 1991. Hydrograph separation: a comparison of geochemical and isotopic tracers. 7. Hydrol., 122, 253-274.
Whitlow, J.R. 1984. A survey of dambos in Zimbabwe. Zimbabme Agric. 7. 81 (4), 129-138. 